\title{
FORUM
}

\section{Knowledge of Insect Diversity in Brazil: Challenges and Advances}

\author{
José A Rafael ${ }^{1}$, Alexandre P Aguiar ${ }^{2}$, Dalton de S Amorim ${ }^{3}$ \\ ${ }^{1}$ Instituto Nacional de Pesquisas da Amazônia (INPA), Coordenação de Entomologia, Av. André Araujo 2936, 69060-001, \\ Manaus, AM; jarafael@inpa.gov.br \\ ${ }^{2}$ Univ. Federal do Espírito Santo, Av Marechal Campos 1468, 29043-900, Vitória, ES; hympar@gmail.com \\ ${ }^{3}$ Depto. de Biologia, Faculdade de Filosofia, Ciências e Letras de Ribeirão Preto, USP, Av. Bandeirantes 3900, \\ 14.040-901 Ribeirão Preto,SP; dsamorim@usp.br
}

Edited by Roberto A Zucchi-ESALQ/USP

Neotropical Entomology 38(5):565-570 (2009)

\section{Conhecimento da Diversidade de Insetos no Brasil: Desafios e Avanços}

RESUMO - Em breve, um milhão de espécies de insetos estará descrita em todo mundo. O Brasil, com cerca de $9 \%$ desse total e possivelmente outras 400 mil espécies ainda não descritas, tem a maior diversidade de insetos. Mas temos cerca de 140 taxônomos ativos, o que significa aproximadamente 3.600 espécies de insetos para cada profissional. Como cada um deles publica em média 100 espécies novas durante sua vida profissional, seriam necessários 2-3 mil anos para descrever toda nossa entomodiversidade. Alguns dos problemas para o desenvolvimento da taxonomia de insetos no Brasil são: dificuldades em obter empréstimos de alguns museus estrangeiros; dificuldades para dissecar espécimes tipos emprestados; depreciação de revistas taxonômicas pela aplicação do fator de impacto; persistência da compreensão limitada do valor do conhecimento taxonômico; legislação restritiva para trabalho de campo; e desrespeito à legislação brasileira que regulamenta sobre o depósito de material biológico coletado no país. Para ações verdadeiramente efetivas para preservação da diversidade biológica no país são necessários: a criação de um centro nacional de informação sobre o conhecimento de diversidade entomológica; investimentos em conjunto de instituições que atuariam como eixos de desenvolvimento do conhecimento taxonômico; investimentos na formação de novos taxonomistas; soluções para os problemas burocráticos que inibem o cumprimento constitucional de conhecimento da biodiversidade; e ações altamente organizadas para conter o desmatamento em áreas de alta diversidade.

PALAVRAS-CHAVE: Entomodiversidade, entomologia, fator de impacto, sistemática, taxonomia

ABSTRACT - Insects will soon reach one million known species worldwide. Brazil, with about $9 \%$ of this total, and possibly another 400 thousand species yet to be discovered, harbors the highest insect diversity in the world. The country has a complement of about 140 active taxonomists, which means a quota of 3,600 insect species per professional. Each Brazilian taxonomist publishes, on average, about 100 species during a professional life span, so it would take 2-3 thousand years to only know the country's insect diversity. Some of the problems hindering the development of insect taxonomy in Brazil are: difficulties with international loans; difficulties with permission for dissecting loaned type specimens; low scientific esteem of taxonomic journals as assessed by the Impact Factor index; academic low esteem of taxonomy knowledge; legal restrictions to field work and disregard of the Brazilian legislation that regulates the final destination of biological material. If truly responsible actions towards preserving biological diversity are to be undertaken nationwide, key problems must be addressed and solved: creation of a national center of information on entomological diversity; investment in a core of institutions that would act as an axis for the development of taxonomic knowledge; investment in the formation of a new generation of taxonomists; elimination of bureaucratic obstacles currently hampering the accomplishment of the constitutional mandate for developing knowledge on biological diversity and developing organized actions to control the deforestation of highly biodiverse areas.

KEY WORDS: Entomology, impact factor, systematics, taxonomy 


\section{How Large is the Insect Diversity in Brazil?}

Insect (Hexapoda) knowledge will soon reach the mark of one million formally described species worldwide. This represents the greatest diversity ${ }^{1}$ of all known groups on Earth, equivalent to around $60 \%$ of all currently described organisms (Grimaldi \& Engel 2005). Brazil is a key country in this context: while Grimaldi \& Engel (2005) counted 925 thousand insect species worldwide, Lewinsohn \& Prado $(2002,2005)$ estimated 110 thousand species $(\sim 12 \%)$ only for Brazil. The most conservative estimates, however, suggest that the total number of species should be at least five times larger, reaching 5 million insect species worldwide (Gaston 1991, Grimaldi \& Engel 2005).

With 8.5 million $\mathrm{km}^{2}$, mostly tropical, but also subtropical, and composed of a mosaic of ecosystems, it is not surprising that Brazil currently houses the highest insect diversity on Earth. Rafael et al (unpublished) pointed to around 90 thousand species of insects in Brazil, close to $9 \%$ of all known insect species (Table 1). However, a reasonable estimate of the real number of insect species based on information from experts in different insect orders should be four to five times larger, reaching 400-500 thousand species (Amorim 2009, Rafael et al unpublished). This would indicate that Brazilian fauna harbors something between 500 thousand and 1 million insect species. A working value of 500 thousand species seems reasonable for the purposes of this work - it is close to both the maximum value of conservative estimates and the minimum value of sensationalist prognoses.

\section{Many Oligo and a few Mega Orders}

Part of the diversity of insects (including basal hexapodan orders Protura, Collembola and Diplura) is distributed among 28 oligodiverse orders, thus called because none exceeds 30 thousand species worldwide. They are: Protura, Collembola, Diplura, Archaeognatha, Zygentoma, Ephemeroptera, Odonata, Plecoptera, Embioptera, Orthoptera, Phasmatodea, Mantophasmatodea, Grylloblattaria, Dermaptera, Zoraptera, Isoptera, Mantodea, Blattaria, Thysanoptera, Psocoptera, Phthiraptera, Neuroptera, Megaloptera, Rhapidioptera, Trichoptera, Mecoptera, Siphonaptera, and Strepsiptera. The oligodiverse Mantophasmatodea, Grylloblattaria, and Rhapidioptera do not occur in Brazil.

Oligodiverse orders have altogether nearly 90 thousand known species worldwide and represent $9 \%$ of the known insect diversity (Table 1). The known number of species in these orders ( $c a .7,300$ species) in Brazil is equivalent to $7.3 \%$ of the world fauna. Zoraptera is the smallest order with six species, while Orthoptera is the largest, with nearly 1,500 species (Rafael et al unpublished). The low relative proportion in relation to the world fauna reflects the lack of specialists, rather than their low diversity in Brazil. Some of these orders never really had any specialist in Brazil, and have been studied by specialists living elsewhere. Indeed, very little is known about most Brazilian oligodiverse insects

${ }^{1}$ The term diversity in this text is synonymous with number of species (= species richness) and urgent efforts should be made to prepare taxonomists for these groups.

The largest insect orders in number of species are referred to as megadiverse. In descending sequence of known species richness, they are: Coleoptera, Lepidoptera, Diptera, Hymenoptera and Hemiptera. Almost 90 thousand species are known to Hemiptera, but with estimates of over 120 thousand, while only 350 thousand species out of over one million estimated species of Coleoptera are known. The five orders combined have $c a$. 903 thousand species, $91 \%$ of the known world insect diversity in number of species (Table 1). In Brazil, these megadiverse orders are represented by nearly 83 thousand known species, $9 \%$ of the world fauna (Rafael et al unpublished). Obviously related to their high number of species, a large number of active taxonomists in Brazil are involved with these few orders.

\section{A Handful of Specialists}

Brazilian academic and research institutions have around 140 active insect taxonomists to study the country's insect diversity (Marques \& Lamas 2006), which would be equivalent to one taxonomist for every 60 thousand $\mathrm{km}^{2}$, an area equivalent to the State of Paraíba, or to one taxonomist for every 700 known insect species known to Brazil. If we consider the estimates of 500,000 as the real number of species in Brazil, there would be actually an average of 3,600 species per taxonomist, which are obviously too many species for any taxonomist, even in a lifetime of intensive work. It takes some decades for any specialist to gather the necessary literature, to develop a full understanding of the morphology and taxonomy of a group, and to build up a collection of specimens of each taxon, e.g., at family level in Insecta. Full working power, hence, is achieved near the end of a career, but such level can only be perpetuated if well trained researchers take over the job soon after a retirement. Decades and generations of effort and knowledge are still observed to vanish in many North American and European countries when a research position is eliminated, due to retirement or replacement by other scientific research areas of interest. In many cases, even if the position is reestablished sometime later, it still demands an extra one or two decades to reach the level of the previous state-of-knowledge. Actually, it is a serious contradiction that research positions in taxonomy have been eliminated during a period when the urgency for

Table 1 Number of world species (Wspp), Brazilian species (BRspp) and respective percentage of world species $(W \%)$ and Brazilian species $(B R \%)$ for the oligodiverse and megadiverse insect orders. Sources: Aguiar et al (in press), Rafael et al (unpublished).

\begin{tabular}{lrrrr}
\hline Insect group & $W s p p$ & $W \%$ & BRspp & BR\% \\
\hline Oligodiverse orders & 90,000 & 9 & 7,300 & 8.0 \\
Megadiverse orders & 903,000 & 91 & 83,000 & 92.0 \\
Total & 993,000 & & 90,300 & 9.0 \\
\hline
\end{tabular}


biodiversity conservation is a worldwide concern.

The scenario provided above for both oligo- and megadiverse insect groups in Brazil indicates a huge task ahead. Considering that the present average number of new species published by Brazilian entomologists is close to three species per year (Aguiar et al in press, Table 6) (or about 100 species during a lifetime), the remaining 400 thousand or so undescribed insect species would take approximately one thousand years to be described by the current core of Brazilian entomologists. Erwin (1982), however, estimated that the number of insect species might be thirty times greater than currently known. If this is correct, it would take two to three thousand years to reach a satisfactory level of knowledge of the Brazilian insect fauna.

\section{The Slowing down of Entomological Research}

Several problems not usually treated in official documents and scientific papers (see Bickel 2009), but which most heavily hinder the advancement of the knowledge on the insect diversity in Brazil are hereby presented and discussed. The points discussed in here are certainly relevant for most taxonomic groups.

\section{The Taxonomist-Museum Relationship}

International loans. The policy adopted in recent years by some foreign museums towards Brazil of not lending or restricting the shipment of type specimens, and in some instances even non-type material, became a critical issue for the fulfillment of taxonomic revisions. Most Brazilian institutions dealing with taxonomy, however, still provide their deposited material to institutions and researchers abroad without any institutional requirement other than a simple loan form. The disastrous policy measures introduced in the recent past in Brazil have been reversed, and no restrictions apply to the movement of material for taxonomic purposes anymore. It should be noted, however, that science will advance in much broader steps if all sides fully and freely cooperate. Obviously, there may still be some problems, but the misdemeanors of a few can hardly justify extreme measures penalizing all. No taxonomists can work alone and all of them need to compare and study specimens of all species without regard to where or when species live or have lived on earth, where specimens where collected, or where specimens are housed (Wheeler 2009).

Extended focus images of type specimens, and online availability of taxonomic revisions and manuals with detailed illustrations help mitigate the problem, reducing the need of loans, but they obviously have limitations in settling taxonomic questions. In our view, it is of the utmost importance that all scientific material that can safely withstand packing and shipping should be made available to all researchers whenever required. Restrictions to material access in foreign institutions that have relevant insect collections or type material certainly reduce the production of quality taxonomic work and hold back the speed of publication.
Difficulties with permission for dissection of loaned type specimens. Some museums do not allow dissection of type specimens due to the risks of damage. Yet a dissected specimen is not a damaged specimen. Restrictions to manipulation and dissection of specimens by students could be understandable, but what is the use of a type specimen if it is helpless for solving problems of species identity?

\section{Contextualization of Taxonomy within the Biological}

\section{Sciences}

Low scientific esteem of taxonomic journals. Quantification and categorization of impact for papers and journals brought a revolution in the way scientists and non-scientists look at scientific publications. Decisions on how the "impact" would be measured are obviously affected by grudging interests and are full of bias, being part of a dispute for power and financial resources. The impact of a paper is obviously related to the overall investment of the scientific community on the published issue. It is clear though that publications related to themes of economic interests will have more citations than others. So this is not a matter of science quality. In such sense, what would be the immediate interest of researchers of all fields on the millions of species to be studied by taxonomists? The impact factor (IF) of taxonomic journals is typically low, usually under 0.8 (see Table 2). It is actually of no surprise that IF and HL (half-life) is inversely correlated: as the perceived importance of species and taxonomic groups grows, papers describing or revising these groups keep being cited. Moreover, the number of websites now gathering all taxonomic information at species level and above, visited by all kinds of information users, provides another measure of the importance of primary taxonomy publications. In taxonomy, however, and even more so in insect taxonomy, peers are rare because specialists are scattered into many different areas. Accordingly, those 140 active taxonomists in Brazil rarely need to or can cite each other.

Indeed, evaluating the "quality" (i.e., impact) of taxonomic publications adopting the same algorithms used for technology-based areas is an idiocy that restrains speed and the accumulation of information on biodiversity. In the newest or most recent areas of research, there is a tendency to concentrate efforts on the development of technology, so papers are pushed to deal with a limited set of problems and solutions. Yet, to efficiently study biodiversity in a world of threatened environments, it is highly recommended that efforts should not be duplicated, so foci should be spread throughout different taxa. Half-life is probably the most adequate criterion for taxonomic journals (Valdecasas et al 2000). The Brazilian agency for evaluation of scientific production and graduate courses (CAPES) already recognizes $\mathrm{HL}$ as a legitimate evaluating criterion, but quite surprisingly does not apply it. In Table 2 it is possible to compare the HL for 2007 and 2008, where the HL is seen to have increased even for journals that had a decrease in their IF.

Zootaxa makes a good example. Zootaxa is the world's leading taxonomic journal in zoology in terms of number of pages and number of taxa published yearly $(1,162$ papers, 24,400 pages published in 2008). Nevertheless, its IF is low 
Table 2 Four important Brazilian journals of wide scope in taxonomic entomology, compared with equivalent journals in developed countries. $I F$, impact factor; $H L$, half-life, in years.

\begin{tabular}{llcrrr}
\hline Region & \multicolumn{1}{c}{ Journal } & IF 2007 & IF 2008 & HL 2007 & HL 2008 \\
\hline Brazil & Neotropical Entomology & 0.546 & 0.46 & 3.7 & 4.4 \\
Brazil & Revista Brasileira de Entomologia & 0.432 & 0.354 & $>10.0$ & $>10.0$ \\
Brazil & Revista Brasileira de Zoologia & 0.422 & 0.403 & 6.4 & 6.7 \\
Brazil & Iheringia, série Zoologia & 0.117 & 0.194 & 5.5 & \\
Australia & Australian Journal of Entomology & 0.684 & 1.072 & 5.9 & 5.2 \\
Canada & Canadian Entomologist & 0.843 & 0.903 & $>10.0$ & $>10.0$ \\
Europe & European Journal of Entomology & 0.734 & 0.913 & 6.6 & 6.3 \\
New Zealand & Zootaxa & 0.691 & 0.74 & 2.2 & 2.4 \\
USA & Proceedings of the Entomological Society of Washington & 0.473 & 0.351 & $>10.0$ & $>10.0$ \\
\hline $\bar{x}$ & & 0.549 & 0.598 & & \\
\hline
\end{tabular}

(0.691 in 2007, 0.74 in 2008) when compared with that of other areas. But how, or even more puzzling, why should taxonomists struggle to raise it? It makes little sense that an entire scientific community, in this case, that of Brazilian taxonomists, suddenly begins to strive into raising the IF of taxonomic journals as a priority in itself. Taxonomic publications must be measured differently, because IFs are just plain incompetent in reflecting the relevance of taxonomic contributions.

Academic low esteem of taxonomy. Comparative biology is a complex area of research despite the common, but deeply naïve perception that it is concerned only with keeping collections of old specimens. Taxonomy deals with the recognition of taxa at the species level and above (Carvalho et al 2008). Information on taxa guides the proposition of evolutionary interpretations for whatever biological trait, from molecules to behavior; standardizes worldwide communication on taxa, providing unique names to taxa across the entire known biodiversity; describes the biodiversity; and furnishes the fundamentals to all decisions on conservation.

Taxa, however, correspond to hypotheses. Bad taxonomy, as the barcoding initiative is a major example (see Song et al 2008, but also see Silva-Brandão et al 2009 for a contrary point of view) is not only useless taxonomy, but also a source of mistakes and misinformation on biodiversity, and therefore pernicious for society (Carvalho et al 2007, 2008). It is a scandalous contradiction the fact that in times of major threats to natural biological resources, taxonomy, the most important tool for biodiversity knowledge, is still seen as a 18th century science. Unfortunately, most scientists are unaware of the revolution in phylogenetics and biogeography reconstruction that began in the 1950s, and now heavily subsidizes areas such as bioinformatics, molecular reconstructions, etc. - the underlying theory of Comparative Biology.

\section{Relationships of Taxonomists with Society at Large}

Legal restrictions to field work. The Brazilian Federal Constitution (Brasil 1988) states that it is up to the public authorities to protect and preserve the biological diversity for future generations (Art. 225). The first logical and methodological step towards the accomplishment of this constitutional mandate is to know what is there to be preserved. Hence, unrestricted access to biodiversity field work for research should be an absolute top priority in environmental legislation. Nevertheless, recent environmental legislation has made field work extremely difficult for Brazilian researchers even from public institutions. Most field collection can now be considered a criminal activity. Access to collecting permits, even for Brazilian researchers, is a bureaucratic nightmare. This is, by all means, the worst that can occur in terms of preserving biological diversity. Furthermore, knowing the areas of endemism and their limits remains largely insufficient, especially for megadiverse groups. This is presently the greatest bottleneck for improving our knowledge on insect biodiversity, while also in blatant contradiction with the Constitution itself.

Disregard of the Brazilian legislation. The Brazilian law regulating the final destination of type material dates back to 1969 (Brasil 1969). It states that all primary types and half of the specimens representing secondary types must be deposited in Brazilian institutions. This law is being disrespected by some foreign researchers. To solve the problem, it would be important to create a supervisory committee responsible for inquiring institutions on all type material collected in Brazil after 1969, and for negotiating their return to the country of origin. The compliance of the international community to these regulations could result in an immediate, positive side effect by alleviating the restrictions imposed by the Brazilian authorities on specimens collection by foreigners.

\section{The Increasing Power of Brazilian Taxonomy}

In May 2009, a report issued by the ISI Web of Science indicated that Brazil had reached the $13^{\text {th }}$ position accounting for $2.12 \%$ of the world scientific production. It may be a surprise only to outsiders that in the same month, Brazil headed outstanding statistics in Zootaxa. In the period 2001-2008, $886(15.7 \%)$ of 5,634 authors that published in 
Zootaxa were from Brazil; of the 5,112 papers published in the same period, $820(16.0 \%)$ have Brazilian authors, $44.4 \%$ of them on entomology. In 2008, the percentage of papers with a Brazilian authorship was $15.0 \%$. So far, so good. This is obviously a limited sample, but the fact that Zootaxa published 24,400 pages last year, way more than any other journal on zoology in the world, slightly reduces the sampling problem.

It is not a question of competition with other countries or with other areas. It is a question of showing how vigorous entomological research is in Brazil, in order to properly undertake the task of dealing with the existing biodiversity. The fact that the country is currently experiencing a major expansion of its Federal Universities promises a substantial increase on the availability of new positions in the field of Zoology. Funding for major projects on taxonomy, however, is largely insufficient. Important initiatives for promoting taxonomy in Brazil in the last 10 years, such as the Program of Training in Taxonomy, supported by CNPq, PRONABIO, PROBIO, PPBio, Biota FAPESP, the Fluminense Atlantic Forest Biodiversity, supported by FAPERJ and FINEP, among others, certainly have had an impact in valuing the place of Brazilian publications in the international scenario. The point, however, is the extent of the task.

Every country, and Brazil in particular, must recognize the unique contribution their fauna can make for the advancement of science. Species biodiversity and museum collections are ultimate treasures of humanity and deserve to be built and shared in a completely open way for the benefit of mankind (Wheeler 2009).

\section{Quo vadis?}

If truly responsible actions to preserve biological diversity are to be undertaken nationwide, different problems must be addressed and solved: (1) creation of a national center of information on entomological diversity in Brazil; (2) investment in a core of institutions which would act as an axis for development of taxonomic knowledge, according to geographical region and availability of taxonomic specialists; (3) investment in the formation of new generations of taxonomists with a solid theoretical background and the ability to effectively convert it into biodiversity knowledge; (4) elimination of the current bureaucratic constraints hampering the accomplishment of the constitutional mandate for developing the knowledge on biological diversity; and (5) development of organized actions to control the deforestation of highly diverse areas.

Solid diagnoses of the situation and sound recommendations and guidance of what to do and how to proceed are actually already available, either locally (e.g., AMNAT 2006, Marques \& Lamas 2006, Aguiar et al in press) or globally (www.cdb. gov.br/COP8). To reduce the gap between what is known on the Brazilian insect fauna and the destruction of natural environments, government and the entomological community should share some common goals. In our opinion, three main goals should be sought: 1) the training of graduate students for high quality taxonomic research, 2) the duplication of current entomology collections and their existing capacity by 2015-2020, especially in megadiverse areas, and 3) the achievement of an overall rate of description (of animals and plants) of 25,000 new species/year by $2015,50,000 /$ year by 2020 and 75,000 by 2050 .

How can we get at least close to these goals? What strategies should be followed? A major effort has been done in the last 25 years by Brazilian authorities and by the zoological research community in Brazil to overhaul and improve the capacity of describing and understanding existing biological diversity in the country. But the size of the gap is still too large relative to the investment made. Of course the use of having all species named is questionable even under a conservative perspective (see, e.g., Bickel 2009). Nevertheless, it is reasonable for the sake of establishing a policy for taxonomic development to have some quantification in mind.

Although environmental issues have become part of everybody's daily concerns, there is still a limited direct investment in biodiversity studies. Carvalho et al (2008) estimated that most of the funds allotted for biodiversity are actually spent in the dissemination, not in the generation of information on biodiversity. This is really ineffective. Despite the enormous amount of international funding now available for investigation on biodiversity, it has been barely used to unveil biodiversity itself. This is a huge mistake, since it could be the most important approach to reduce the gap between researchers and biodiversity. Furthermore, it is not even really necessary to have gigantic funding of some major institutions to properly lead the way.

\section{Acknowledgments}

To Dr Carlos José Einicker Lamas (Museu de Zoologia de São Paulo), Dr Claudio José Barros de Carvalho (Univ. Federal do Paraná) and Roger Hutchings (Instituto Nacional de Pesquisas da Amazônia) for useful discussions and suggestions on early versions of the manuscript. Laurence Mound (CSIRO, Canberra, Australia) reviewed the submitted manuscript and contributed with important suggestions.

\section{References}

Aguiar A P, Santos B F, Couri M S, Rafael J A, Costa C, Ide S, Duarte M, Grazia J, Schwertner C F, Freitas A V L, Azevedo C O (in press). Entomologia. In Rocha R M, Boeger W A P (orgs) Zoologia: estado da arte e perspectivas para os próximos 10 anos. Curitiba, Universidade Federal do Paraná.

AMNAT (Associação Memória Naturalis) (2006) Biodiversity the megascience in focus. Outcomes and recommendations of the COP8 associated meeting, and a statement of principles by Brazilian biodiversity scientists. Rio de Janeiro, Museu Nacional, Série Livros 20, 44p.

Amorim D S (2009) Neotropical Diptera diversity: richness, patterns, and perspectives, p.71-97. In Pape T, Bickel D, Meier $\mathrm{R}$ (eds) Diptera diversity: status, challenges and tools. Leiden, Koninklijke Brill, 459p. 
Bickel D (2009) Why Hilara is not amusing: the problem of openended taxa and the limits of taxonomic knowledge, p.279-301. In Pape T, Bickel D, Meier R (eds) Diptera diversity: status, challenges and tools. Leiden, Koninklijke Brill, 459p.

Brasil (1969) Decreto número 65.057 de 26 de agosto de 1969, publicado no Diário Oficial da União em 27 de agosto de 1969.

Brasil (1988) Constituição da República Federativa do Brasil de 1988. http://www.planalto.gov.br/ccivil_03/constituicao/ constituição.htm

Carvalho M R de, Bockmann F A, Amorim D S, Brandão C R F (2008) Systematics must embrace comparative biology and evolution, not speed and automation. Evol Biol 35: 97-104.

Carvalho M R de, Bockmann F A, Amorim D S, Brandão C R F, Vivo M de, Figueiredo J L de, Britski H A, Pinna M C C de, Menezes N A, Marques F P L, Papavero N, Cancello E M, Crisci J V, McEachran J D, Schelly R C, Lundberg J G, Gill A C, Britz R, Wheeler Q D, Stiassny M L J, Parenti L R, Page L M, Wheeler W C, Faivovich J, Vari R P, Grande L, Humphries C J, DeSalle R, Ebach M C, Nelson G J (2007) Taxonomic impediment or impediment to taxonomy? a commentary on systematics and the cybertaxonomic-automation paradigm. Evol Biol 34: 140-143.

Erwin T L (1982) Tropical forests: their richness in Coleoptera and other arthropod species. Coleopt Bull 36: 74-75.

Gaston K J (1991) The magnitude of global insect species richness. Cons Biol 5: 283-296.
Grimaldi D, Engel M S (2005) Evolution of the insects. New York, Cambridge University Press, $x v+755 p$.

Lewinsohn T M, Prado P I (2002) Biodiversidade brasileira. Síntese do estado atual do conhecimento. São Paulo, Ed. Contexto, 176p.

Lewinsohn T M, Prado P I (2005) Quantas espécies há no Brasil? Megadiversidade 1: 36-42.

Marques A C, Lamas C J E (2006) Taxonomia zoológica no Brasil: estado da arte, expectativas e sugestões de ações futuras. Pap Av Zool 46: 139-174.

Silva-Brandão K, Lyra M L, Freitas A V L (2009) Barcoding Lepidoptera: current situation and perspectives on the usefulness of a contentious technique. Neotrop Entomol 38(4): 441-451.

Song H, Buhay J E, Whiting M F, Crandall KA(2008) Many species in one: DNA barcoding overestimates the number of species when nuclear mitochondrial pseudogenes are coamplified. PNAS 135: 13486-13491.

Valdecasas A G, Castroviejo S, Marcus L F (2000) Reliance on the citation index undermines the study of biodiversity. Nature 403: 698 .

Wheeler Q D 2009 Revolutionary thoughts on taxonomy: declarations of independence and interdependence. Zoologia 26: 1-4.

Received 19/VI/09. Accepted 02/VII/09. 